\title{
Contributions and Challenges
}

\author{
Wie kann und sollte die Zivilgesellschaft am globalen Finanzsystem beteiligt \\ werden? Es ist festzustellen, dass ihre Bedeutung wächst. Trägt sie zu einer \\ effektiven Steverung der globalen Finanzmärkte bei oder gilt eher das Gegen- \\ teil? Eine Bilanz ergibt ein ambivalentes Bild. Die Rolle der Zivilgesellschaft \\ sollte weder idealisiert noch dämonisiert werden.
}

$\mathrm{C}$ Von Jan Aart Scholte ivil society is an arena of growing importance in global financial governance. But we should neither romanticise nor demonise civil society involvement in global finance. This activity is not inherently good or bad. The challenge is to maximise the benefits and minimise the downsides. To demonstrate the overall argument, the discussion below first briefly describes the globalisation of finance and reviews the complex network of agencies that make up the governance of global finance, as well as the main challenges that the governance of global finance faces. Then the rise of civil society initiatives on global finance is briefly surveyed. The remainder of the article notes the various positive potentials and negative possibilities in civil society engagement of global financial governance and draws up a balance sheet (1).

\section{- Financial Globalisation}

The financial sector has shown some of the most far-reaching globalisation in recent history. Huge amounts of savings and credits now flow in a worldscale reservoir where territorial distances and territorial borders exert substantially fewer constraints than they once did. Electronic communications allow money, bank deposits, loans, securities, derivatives and other financial dealings to move between any points on the planet in no time. The principal financial companies have organised themselves as global enterprises. Savers look to the world as a whole as their field of investment.

Of course this is not to say that territorial geography has lost all importance in contemporary finance. Nor is it to imply that the globalisation of finance has touched all parts of humanity to the same extent or with the same effects. The point is that growing supraterritorial aspects of economic geography have substantially altered the spatial character of finance, and this change has far-reaching implications for the way that we govern the sector (2).
The globalisation of finance is evident in many areas. For example, certain money forms circulate in a transworld sphere. Various currencies like the dollar and the yen are used in transactions that never touch the soil of the issuing country. Foreign exchange trading reached an average daily volume of 1,5 trillion US dollars in 1998 . Global credit cards have become a regular means of payment for several hundred million people. Banking has also substantially globalised. The world total of bank deposits owned by non-residents of a given country rose from 20 billion dollars in 1964 to 7.900 billion dollars in 1995, including several trillion dollars' worth in offshore accounts. Electronic payments through the Society for Worldwide Interbank Financial Telecommunications (SWIFT) averaged more than 5 trillion dollars per day in 1999. Outstanding balances on syndicated transborder bank loans rose from under 200 billion dollars in the early 1970s to over 10.000 billion dollars in 1990. Other global lending has occurred on a notable scale through official financial institutions such as the International Monetary Fund (IMF) and the multilateral development banks.

Contemporary securities markets have also acquired substantial global attributes. For example, the largely supraterritorial eurobond market has grown from its inception in 1963 to a level of 371 billion dollars in new borrowings in 1995 . The two main clearing houses for transborder securities trading, Euroclear and Clearstream, together reached an annual turnover of nearly 60 trillion dollars in 1999.

Additional globalisation has occurred in respect of the financial derivatives business, an industry that has burgeoned since the early 1970s. At the end of 1999 the notional amount of outstanding over-the-counter financial derivative contracts -thus excluding exchange-based derivatives - reached 88 trillion dollars. Much insurance business has also gone global.
In short, much contemporary finance has a global character that was barely if at all evident before 1960. The sums involved are staggering, dwarfing the numbers associated with sales turnover in other sectors of the global economy. It is understandable in this light that many worries regarding ,globalisation out of control" have concerned finance.

\section{Global Financial Governance}

Any sector of the economy is governed. It operates with norms, established procedures, technical standards, definitions. So it is with global finance as well. There are rules for foreign exchange dealing, for transborder bank deposits and loans, for global bond and equity business, for derivatives markets, for transworld insurance.

This is not the place for details, but we should note the general point that the governance of global finance is multilayered and diffuse. It is multilayered across national, regional, global and local levels, involving state, interstate, transstate, suprastate and substate agencies. It is diffuse between a plethora of institutions in both the public and the private sector.

Now almost no one argues that current regulatory arrangements for global finance are satisfactory. There are efficiency problems, in terms of data deficits, market concentration, and a worry that global finance capital diverts investment from the real economy. There are also stability problems, with a widely held view that global financial markets are inordinately volatile. There are human security problems, in the sense that global financial regimes can operate - perhaps unintentionally - to exacerbate poverty or environmental damage. Then there are equity problems, as current structures of global finance often arbitrarily favour Northern countries, big corporate players, high-income groups, and men. Finally, there are democracy problems. Current arrangements of global financial governance are widely felt to be insufficiently participatory, consultative, representative, transparent and publicly accountable.

Mounting concerns about these various policy challenges have generated much discussion in recent years about change in the so-called global financial architecture. Innumerable suggestions have circulated to establish new principles, new policies, and new institutional mechanisms to govern global finance. It is likely that the coming years will bring change in global financial governance, though its extent, speed, and direction remain to be determined. 


\section{Wenninger- \\ Anzeige \\ bitte aus \\ Punkt.um \\ 6/01 S. 8 \\ entnehmen}

\section{Civil Society Initiatives}

What can civil society contribute to alleviating the problems of global finance and its governance reviewed above? The notion of civil society is open to multiple interpretations, but for present purposes we might define it as a political space where voluntary associations attempt deliberately to shape the rules that govern one or the other aspect of social life. These efforts involve all manner of groups: local and global; formal and informal; status quo and revolutionary. Civil society includes - but is not limited to - NGOs (nongovernmental organisations).

The main sectors of civil society that have engaged with questions of global finance are

- business forums like the Institute of International Finance,

development NGOs like Oxfam,

environmental NGOs like Friends of the Earth,

trade unions like the International Confederation of Free Trade Unions,

policy research institutes like the Overseas Development Council, and

- faith-based groups, principally connected to Protestant and Roman Catholic churches.

These associations have addressed five main concerns in global finance:

1. Some of the most high-profile civil society activity of recent years has concerned the transborder debt problems of poor countries. The Jubilee 2000 campaign, with affiliates in over 60 countries, has stood out in this regard in recent years.

2. Many civil society groups have lobbied on the social and environmental aspects of project loans by multilateral development banks, especially the World Bank.

3. Various civil society initiatives have since the early 1980s addressed structural adjustment lending, mainly from the IMF and the World Bank.

4. Certain civil society organisations have given attention to the workings of commercial global finance - for example, with proposals for a Tobin tax and so-called ethical investment. On the whole, however, NGOs, religious bodies and trade unions have accorded surprisingly little priority to commercial global finance, in spite of its huge proportions as described earlier.

5 . Finally, in recent years some civil society organisations have joined debates on the so-called global financial architecture.

True, we should not exaggerate the scale of these activities. Moreover, the forms and intensity of civil society activism on global finance have varied considerably between different parts of the world. These qualifications noted, however, it is clear that civil society has become an important dimension of the politics of global economic governance. Should we welcome or deplore this development?

As noted at the outset of this article, this assessment seeks neither to celebrate nor to denigrate civil society involvement in global finance. Both positive and negative potentials can be identified.

\section{Positive Potentials}

In terms of positive contributions, civil society engagement might yield at least seven types of benefits. One is public education. Civil society organisations (CSOs) can raise citizens' awareness and understanding of global finance and its governance. A second positive effect is participation. Civil society can provide a venue for stakeholders to make inputs to policy processes. In particular, civil society can open opportunities for participation to social circles that are otherwise excluded from public decision-taking on global finance.

Third, civil society associations can fuel debate about global finance. Effective governance rests on vigorous, uninhibited discussion of diverse views. Civil society can promote that diversity and spark critical, creative policy debate. Fourth, civil society can contribute positively by increasing public transparency around global finance. Civil society actors can push financial markets and regulatory authorities to be more open about their operations, thereby enhancing both efficiency and democracy. Fifth, civil society involvement can raise public accountability in the way that global finance is governed. Civil society can push regulatory agencies in global finance to take public responsibility for their actions. Sixth, CSOs can contribute positively in respect of welfare. Service delivery through CSOs can help to counter the economic and social fallout of financial difficulties.

Through these various means, civil society can, seventh, enhance the legitimacy of global financial governance. Civil society activities can allow people to feel that they ,own“ the process of global finance and that it works in their interest. So civil society has considerable positive potential in the area of global finance.

\section{Potential Problems}

However, there are also potential problems, whereby civil society might actually detract from rather than enhance effective governance of global finance. Five such negative points can be 
mentioned. First, there is the potential problem of ,uncivil society“. CSOs may pursue special privileges rather than public interests, and they may employ harmful means in pursuit of dubious goals. Second, civil society initiatives on global finance might suffer from low quality. The campaigns can be poorly conceived and/or ineptly executed. Third, problems of low quality may also arise in official circles. That is, governance institutions may prove to be poorly equipped to handle civil society inputs, in terms of resources, procedures and attitudes. Fourth, civil society inputs may be compromised by undemocratic practices. In other words, civil society groups may in their own operations be insufficiently participatory, consultative, transparent or accountable. Finally, civil society can have representation problems. Involvement in civil society mobilisation on global financial issues may be biased, for example, to the North, to wealthier circles, to men, whites, Christians and/or urban dwellers.

\section{- Drawing up a Balance Sheet}

Drawing these various positive and negative possibilities together, we can ask - as many commentators of late have done: Is civil society activity in respect of global finance legitimate? Do civil society associations have a right to exert authoritative influence in the politics of global financial governance? The answer can be yes if civil society inputs to global financial governance meet one or several of three grounds:

1. Civil society actors may have performance legitimacy. That is, their right of involvement and influence may derive from their information, knowledge, competence, expertise, cost effectiveness, and so on.

2. Civil society actors may have democratic legitimacy, in two senses: they may advance public participation and public accountability in global financial governance; and they may fulfil democratic criteria in their own operations.

\section{Der Autor}

Jan Aart Scholte is Reader in International Studies and Associate of the Centre for the Study of Globalisation and Regionalisation (CSGR) at the University of Warwick.

Kontakt: CSGR, University of Warwick, Coventry, CV4 7AL, Großbritannien. Tel. 0044-24-765-72939, Fax-24221, E-mail: scholte@warwick.ac.uk

3. Civil society actors may have moral legitimacy: in terms of noble objectives and playing the role of a global conscience.

So there are reasons to accept - and indeed be enthusiastic about - civil society engagement of global finance. There are also reasons to be cautious. The challenge ahead is to identify the situations and the practices where we maximise the promises and minimise the pitfalls of civil society involvement in global finance.

\section{Literatur zum Schwerpunkt}

Andresen, S.: Science and politics in international regimes: between integrity and involvement. Manchester u.a. 2000: Manchester University Press

Bendell, J. (ed.): Terms for Endearment: Business, NGOs and Sustainable Development. Sheffield 2000: Greenleaf

Brand, U.: Nichtregierungsorganisationen, Staat und ökologische Krise. Konturen kritischer NRO-Forschung. Münster 2000

Brand, U./ Brunnengräber, A./ Schrader, L./ Stock, C./ Wahl, P.: Global Governance - Alternative zur Neoliberalen Globalisierung? Münster 2000

Cohen, R. (ed.): Global social movements. London U.a. 2000: Athlone Press

Cole, M.A.: Trade liberalisation, economic growth and the environment. Cheltenham 2000: Eduard Elgar

DeSombre, E.R.: Domestic sources of international environmental policy : industry, environmentalists, and US power. Cambridge MA u.a. 2000: MIT Press

Hein, W./ Fuchs, P. (Hrsg.): Globalisierung und ökologische Krise. Hamburg 1999: Dt. Übersee-Institut

Held, D.: Global transformations : politics, economics and culture. Cambridge u.a. 1999: Polity Press

Hewson, M./ Sinlaird, T.J. (eds.): Approaches to Global Governance Theory. New York 1999: SUNY Press

Higgott, R.A. (ed.): Non-state actors and authority in the global system. London 2000: Routledge

Jänicke, M. / Jörgens, H. (Hrsg.): Umweltplanung im internationalen Vergleich. Strategien der Nachhaltigkeit. Berlin u.a. 2000

Kaul, I./ Grunberg, I./ Stern, M. (eds.): Global Public Goods : International Cooperation in the 21 st Century. Oxford 1999: Oxford University Press

Keck, M.E./ Sikkink, K.: Activists beyond Borders: Advocacy Networks in International Politics.

\section{References}

(1) This article summarises the concerns of the Civil Society and Global Finance Project, a collaborative endeavour of the Centre for the Study of Globalisation and Regionalisation at the University of Warwick and the Peace and Governance Programme of the United Nations University. The full findings will be published in book form in early 2002 (Scholte, J.A. with Schnabel, A. (eds.): Civil Society and Global Finance. Routledge, London).

(2) This general analysis of globalisation is developed further in Scholte, J.A.: Globalization: A Critical Introduction. Palgrave, Basingstoke 2000.
Ihaca 1998: Cornell University Press

King, A./ Lenox M.: Industry self-regulation without sanctions: The chemical industry's responsible care program. In: Academy of Management Journal, Vol. 43(2000), №. 4

Klein, A. et al.: Neve soziale Bewegungen - Impulse, Bilanzen und Perspektiven. Opladen 1999

Kolk, A.: Economics of environmental management. Harlow 2000: Prentice Hall

Kreibich, R./ Simonis, U.E. (Hrsg.): Global Change Globaler Wandel. Ursachenkomplexe und Lösungsansätze. Berlin 2000.

O'Brian, R./ Goetz, A.M./ Scholte, J.A./ Williams, M.: Contesting Global Governance. Multilateral Economic Institutions and Global Social Movements. New York 2000: Cambridge University Press

Paterson, M.: Understanding global environmental politics: domination, accumulation, resistance. Basingstoke u.a. 2000: Macmillan

Prakash, A.: Greening the Firm: The Politics of Corporate Environmentalism. Cambridge 2000: Cambridge University Press.

Reinicke, W. H.: Global Public Policy. Governing without Government? New York 1998: Brookings Instution Press

Väyrynen, R. (ed.): Globalization and global governance. Lanham u.a. 1999: Rowman \& Littlefield

WBGU: Welt im Wandel - Neue Strukturen globaler Umweltpolitik. Jahresgutachten 2000. Berlin u.a. 2001

Werle, R./ Schimank, U. (Hrsg.): Gesellschaftliche Komplexität und kollektive Handlungsfähigkeit. Frankurt/New York 2001.

Zürn, M.: Regieren jenseits des Nationalstaates. Globalisierung und Denationalisierung als Chance. Frankfurt a.M. 1998 
(c) 20I0 Authors; licensee IÖW and oekom verlag. This is an article distributed under the terms of the Creative Commons Attribution Non-Commercial No Derivates License (http://creativecommons.org/licenses/by-nc-nd/3.o/), which permits unrestricted use, distribution, and reproduction in any medium, provided the original work is properly cited. 